\title{
Crop water requirement (ETc) of different crops of middle Gujarat
}

\author{
RASHMI MEHTA and VYAS PANDEY \\ Department of Agricultural Meteorology \\ Anand Agricultural University, Anand 388110, Gujarat \\ Email: rashmi.tca@gmail.com
}

\begin{abstract}
Accurate estimation of crop water requirements (ETC) of any crop is essentially required for irrigation scheduling and water management. The present study was undertaken to estimate the crop water requirement (ETc) of ten major crops (rice, wheat, maize, pearl millet, chickpea, green gram, soybean, groundnut, mustard and cotton) grown in different seasons inmiddle Gujarat region. The daily reference evapotranspiration (ETo) was estimated by FAO Penman-Monteith method using 20 years (1993 to 2013) mean meteorological data of Anand. The growth stage wise crop coefficients (Kc) modified for daily climatic variation was used to estimate the daily ETc for the selected crops. The daily ETo was found to increase continuously from $4.2 \mathrm{~mm}^{\text {day }}{ }^{-1}$ in January to its maximum values of $10.1 \mathrm{~mm}^{\text {day }}{ }^{-1}$ during $25^{\text {th }}-30^{\text {th }}$ May, thereafter ETo decreased sharply during June and remained low during July and August ( $\mathrm{H}^{\prime \prime} 5.4 \mathrm{~mm}$ day $\left.^{-1}\right)$. With slight increase during September and October, it decreased further and reached to its minimum value $\left(4.0 \mathrm{~mm} \mathrm{day}^{-1}\right)$ at the end of year. The seasonal crop water requirement (ETc) estimates showed that, among summer crops, groundnut has higher ETc $(849.0 \mathrm{~mm})$ value than pearlmillet $(499.2 \mathrm{~mm})$ and green gram $(476.5 \mathrm{~mm})$. Among kharif crops, cotton $(848.0 \mathrm{~mm})$ and rice $(729.3 \mathrm{~mm})$ have the highest crop water requirement whereas pearlmillet $(323.6 \mathrm{~mm})$ and green gram $(324.6 \mathrm{~mm})$ have the lowest ETc. Amongst winter season crops, wheat has the highest $(501.2 \mathrm{~mm}) \mathrm{ETc}$ and mustard has the lowest $(411.7 \mathrm{~mm})$ ETc. These results can be used in efficient management of irrigation water.
\end{abstract}

Keywords : Reference evapotranspiration (ETo), crop water requirement (ETc), crop coefficient (Kc), cereals, pulses, oilseeds, cotton

The effective use of water both in irrigated and rainfed area for crop production is essential. The adoption of exact or correct amount of water and correct timing of application is very essential for scheduling irrigations to meet the crop's water demands and for optimum crop production. Jensen et al. (1990) provided detailed reviews of the methods commonly used to determine evapotranspiration and crop water requirements. The irrigation scheduling based on crop water requirement (ETc) determined by multiplying crop coefficient $(\mathrm{Kc})$ values with reference evapotranspiration (ETo), is one of the widely used method (Doorenbos and Pruitt 1975). Based on availability of weather data, various methods (BlaneyCriddle 1950; Turc 1961; Christiansen 1968; Priestly-Taylor 1972; Hargreaves-Samani 1985; FAO Penman-Monteith method: Allen et al. 1998) have been suggested. Among all the methods Penman-Monteith method (Allen et al. 1998) has been reported to yield consistently more accurate reference evapotranspiration(ETo) estimates across a wide range of climate condition (Jensen et al. 1990; Kashyap and Panda 2001; Irmak et al. 2003). Since Kc values are found to be crop, location and season specific, hence, need to be corrected for each location (Shanker et. al. 2012; Mehta and Pandey 2015) to determine ETc.

In this paper, an attempt has been made to determine the crop coefficient $(\mathrm{Kc})$ and crop water requirement (ETc)for kharif (rice, maize, pearlmillet, greengram, soybean, groundnut, cotton), winter (wheat, maize, chickpea, mustard) and summer (pearlmillet, green gram, groundnut) season crops based on ETo computed using long period weather data of Anand, Gujarat India.

\section{MATERIALS AND METHODS}

Anand is located at latitude $22^{\circ} 32^{\circ} \mathrm{N}$, longitude $72^{\circ}$ 59' E and altitude $45.1 \mathrm{~m}$. The daily weather data (maximum temperature, minimum temperature, morning relative humidity, afternoon relative humidity, sunshine hour and wind speed) for twenty years period (1993 to 2013) of Anand were obtained from Agromet data bank, Department of Agricultural Meteorology, Anand Agricultural University, Anand and was used to calculate reference evapotranspiration (ETo) following Allen et al.(1998). 


\section{Estimation of reference evapotranspiration (ETo)}

Penman-Monteith method as given in FAO-56 (Allen et al. 1998) was used for computation of reference evapotranspiration (ETo).

ETo $=\frac{0.408 \Delta\left(R_{n}-G\right)+\gamma \frac{900}{T_{a}+273} u_{2}\left(e_{s}-e_{a}\right)}{\Delta+\gamma\left(1+0.34 u_{2}\right)}$

Where, ETo is reference evapotranspiration ( $\mathrm{mm}$ day $\left.{ }^{1}\right), R_{n}$ is net radiation at the crop surface $\left(\mathrm{MJ} \mathrm{m}^{-2} \mathrm{day}^{-1}\right), \mathrm{G}$ is soil heat flux density $\left(\mathrm{MJ} \mathrm{m}^{-2} \mathrm{day}^{-1}\right), \mathrm{T}_{\mathrm{a}}$ is mean daily air temperature $\left({ }^{\circ} \mathrm{C}\right), \mathrm{u}_{2}$ is wind speed at $2 \mathrm{~m}$ height $\left(\mathrm{m} \mathrm{s}^{-1}\right), \mathrm{e}_{\mathrm{s}}$ is saturation vapor pressure $(\mathrm{kPa}), \mathrm{e}_{\mathrm{a}}$ is actual vapor pressure $(\mathrm{kPa}), \mathrm{e}_{\mathrm{s}}-\mathrm{e}_{\mathrm{a}}$ is saturation vapor pressure deficit $(\mathrm{kPa}), \mathrm{A}$ is slope of saturation vapor pressure curve $\left(\mathrm{kPa}^{\circ} \mathrm{C}^{-1}\right)$ and $\mathrm{O}$ is psychrometric constant $\left(\mathrm{kPa}^{\circ} \mathrm{C}^{-1}\right)$.

Mean value of all six weather parameters $\left(\mathrm{T}_{\max }\right.$, $\mathrm{T}_{\min }, \mathrm{RH}_{\max }, \mathrm{RH}_{\min }, \mathrm{n}$ and $\mathrm{u}_{2}$ ), altitudes and latitudes were used to compute each parameter required for PenmanMonteith model namely: slope of saturation vapor pressure $(\Delta)$, psychrometric constant $(\gamma)$, extraterrestrial radiation $\left(\mathrm{R}_{\mathrm{a}}\right)$, solar radiation/short wave radiation $\left(\mathrm{R}_{\mathrm{s}}\right)$, inverse relative distance earth-sun $\left(\mathrm{d}_{\mathrm{r}}\right)$, solar declination $(\delta)$, sunset hour angle $\left(\omega_{\mathrm{s}}\right)$, daylight hours $(\mathrm{N})$, clear-sky solar radiation $\left(\mathrm{R}_{\mathrm{so}}\right)$, net solar or net shortwave radiation $\left(\mathrm{R}_{\mathrm{ns}}\right)$, net long wave radiation $\left(\mathrm{R}_{\mathrm{n} 1}\right)$, net radiation $\left(\mathrm{R}_{\mathrm{n}}\right)$ and soil heat flux density $(\mathrm{G})$ through programme developed in MS Excel. The detail of methodology has been described by Mehta and Pandey (2015).

\section{Crop coefficient (Kc)}

To determineKc values for different crops, the total crop growing period was divided into four growth stages (initial, developmental, mid-season and late-season). The crop coefficient $\left(\mathrm{Kc}_{\text {mid }}\right.$ and $\left.\mathrm{Kc}_{\text {end }}\right)$ values were corrected as follnure

$$
\begin{aligned}
& \mathrm{Kc}_{\text {mid }}=\mathrm{Kc} c_{\text {mid (tab) }}+\left[0.04\left(\mathrm{u}_{2}-2\right)-0.004\left(\mathrm{RH}_{\min }-45\right)\right]\left[\frac{\mathrm{h}}{3}\right]^{0.3} \\
& \mathrm{Kc}_{\text {end }}=\mathrm{Kc} c_{\text {end (tab) }}+\left[0.04\left(\mathrm{u}_{2}-2\right)-0.004\left(\mathrm{RH}_{\min }-45\right)\right]\left[\frac{\mathrm{h}}{3}\right]^{\text {.3. }}
\end{aligned}
$$

Where;

$\mathrm{Kc}_{\text {mid(Tab) }}=$ value for $\mathrm{Kc}_{\text {mid }}$ taken from reference table (Table 1),

$\mathrm{Kc}_{\text {end (Tab) }}=$ value for $\mathrm{Kc}_{\text {end }}$ taken from reference table (Table 1),

$\mathrm{u}_{2}=$ mean value for daily wind speed at $2 \mathrm{~m}$ height over grass during mid season growth stage $\left(\mathrm{m} \mathrm{s}^{-1}\right)$, for $1 \mathrm{~m} \mathrm{~s}^{-1} \mathrm{~d}^{\prime} \mathrm{u}_{2} \mathrm{~d}$ " $6 \mathrm{~m}$ $\mathrm{s}^{-1}$,

$\mathrm{RH}_{\min }=$ mean value of daily minimum relative humidity during mid season growth stage (\%), for $20 \% \mathrm{~d}^{\prime} \mathrm{RH}_{\min }$ d" $80 \%$,

$\mathrm{h}=$ mean plant height during mid season growth stage $(\mathrm{m})$ for $0.1 \mathrm{~m}<\mathrm{h}<10 \mathrm{~m}$.

The daily crop coefficient (Kc) values for developmentalstage and late season stage for each of the crop were determined throughlinear interpolation.

\section{Crop evapotranspiration/Crop water requirement (ETc)}

In the present study, crop water requirement (ETc) was determined on daily basis by multiplying daily reference evapotranspiration (ETo) with crop coefficient (Kc) value (Doorenbos and Pruitt 1975).

$$
\mathrm{ETc}=\mathrm{Kc} * \mathrm{ETo}
$$

The daily ETc computed were summed for different growth stages (initial, developmental, mid-season and lateseason) of crop and seasonal crop water was determined.

\section{RESULTS AND DISCUSSION}

\section{Daily variation of reference evapotranspiration (ETo)}

The daily ETo from January to December (Fig. 1) varied between 4.0 to $10.1 \mathrm{~mm}^{\text {day }}{ }^{-1}$. The ETo increased continuously from January $\left(4.2 \mathrm{~mm}^{-1 a y^{-1}}\right)$ and reached to its peak during May $\left(10.1 \mathrm{~mm} \mathrm{day}^{-1}\right)$. It sharply decreased during June and remains low in July and August (4.6 to 5.8 $\left.\mathrm{mm} \mathrm{day}^{-1}\right)$, thereafter it slight increased during September and October (upto $6.2 \mathrm{~mm} \mathrm{day}^{-1}$ ). It decreased afterwards and reached to the minimum value during December $(4.0 \mathrm{~mm}$ day $\left.^{-1}\right)$. The variation in ETo is attributed to daily variation in wind speed, temperature and $\mathrm{RH}_{\text {min }}$ during the year. Since the climatic parameters vary with locations therefore ETo also varies with the locations (Mehta and Pandey, 2015).

\section{Corrected crop coefficient (Kc)}

As the Kc value is influenced by weather parameters and crop growth stages, its value differed not only from stage to stage but also varied with crops. The corrected $\mathrm{Kc}$ values along with FAO Kc values and crop specific parameters for ten selected crops are given in Table 1. The total crop duration ranged between 90 days for pearl millet and green gram to 190 days for cotton. The initial stage generally varied between 15 to 30 days while developmental stage varied between 30 to 45 days; mid-season varied between 35 to 60 daysand late season varied between 30 to 45 days for most of the crops.Among kharif(June-October) season crops (rice, maize, pearlmillet, green gram, soybean, groundnut, cotton) the corrected Kc values were less than 


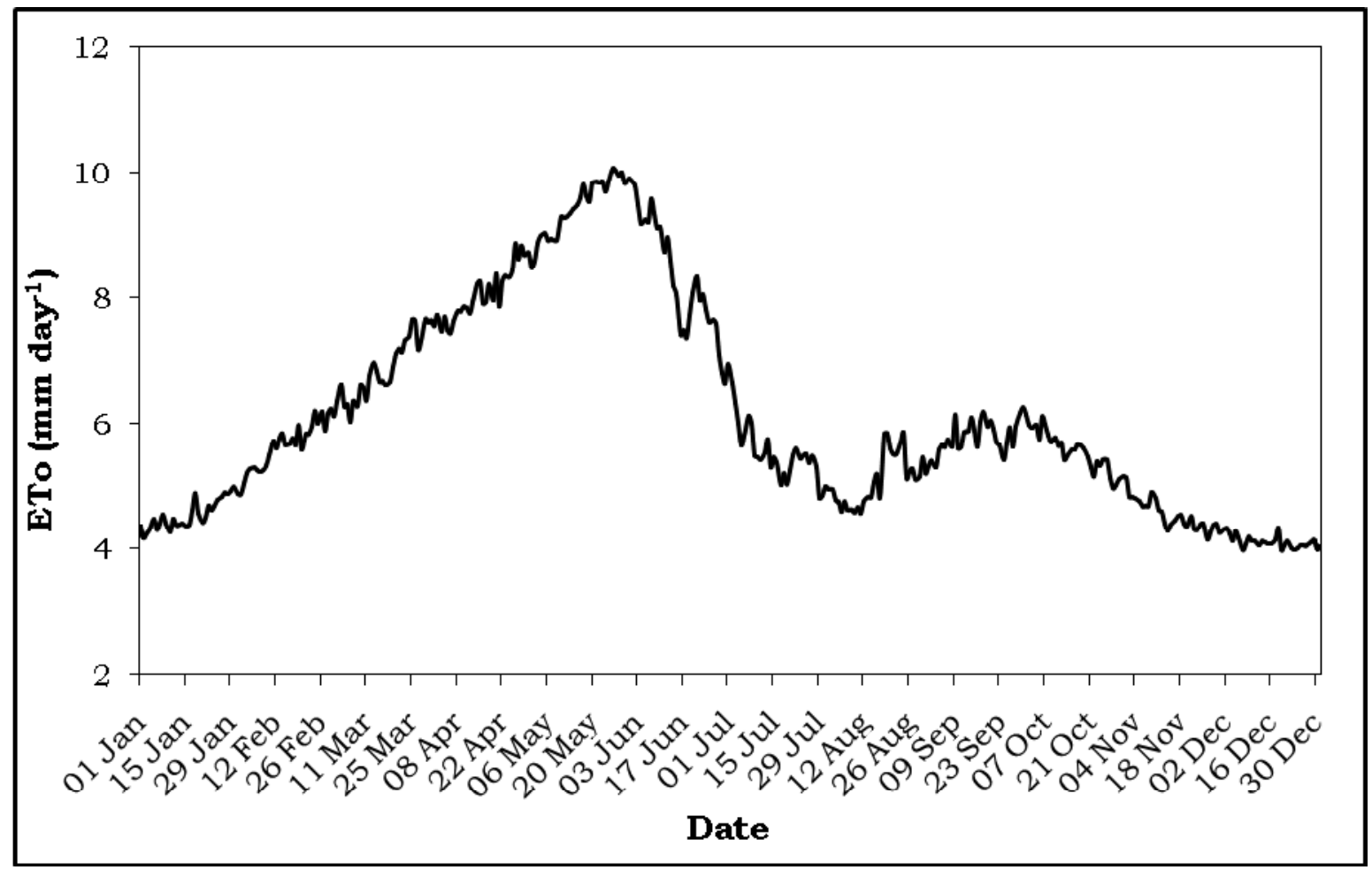

Fig. 1: Mean daily variation of reference evapotranspiration (ETo) at Anand, Gujarat

that of FAO reported values for all crops except rice and cotton in which there was no difference.Inwinter season crops (wheat, maize, chickpea, mustard) grown during (November-February) there was no difference between FAO values and corrected Kc values while for summer season (February-May) crops (pearlmillet, green gram groundnut) the correctedKc values for groundnut was less than FAO reported values.

\section{Stage wise crop water requirement (ETc)}

ETc of kharif crops: The stage wise crop water requirement of different crops (Table 2) suggested that among kharif season crops cotton has the highestETc $(848.0 \mathrm{~mm})$ followed by rice $(729.3 \mathrm{~mm})$ while the pearl millet $(323.6 \mathrm{~mm})$ and green gram $(324.6 \mathrm{~mm})$ have the lowest ETc. During the initial stage of the crops, rice has the highest $(83.8 \mathrm{~mm})$ water requirement at the rate of $5.6 \mathrm{~mm} \mathrm{day}^{-1}$ followed by cotton $(71.5 \mathrm{~mm})$ at the rate of $2.4 \mathrm{~mm} \mathrm{day}^{-1}$. Soybean and groundnut have ETc of $59.0 \mathrm{~mm}$ each at the rate of $3.0 \mathrm{~mm} \mathrm{day}^{-1}$ during their initial stage. During developmental stage the ETc for different crops varied between 66.5 to $173.9 \mathrm{~mm}$, highest being in cotton and lowest in green gram with daily rate of 3.1 to $5.7 \mathrm{~mm}$ day $^{-1}$. Mid-season is the longest stage of the crop during which water requirement is also maximum. ETc of different crops during mid-season varied between 161.9 to $422.1 \mathrm{~mm}$ with daily rates ranging between 5.0 to $6.9 \mathrm{~mm}$ day $^{-1}$. During late season the water requirement decreases, hence depending upon the duration of the crops the total ETc of different crops varied between 46.8 to $180.5 \mathrm{~mm}$, the highest being in cotton and lowest in pearl millet. The daily rate of ETc during late season ranged between 3.1 to $5.4 \mathrm{~mm}$ day $^{-1}$.

ETc of winter (rabi) crops: The seasonal crop water requirement $(\mathrm{ETc})$ of winter season cropsvaried between $411.7 \mathrm{~mm}$ in chickpea to $501.2 \mathrm{~mm}$ in wheat (Table 2). Maize and mustard have seasonal ETc of $420.3 \mathrm{~mm}$ and $469.1 \mathrm{~mm}$ respectively. During initial stage of the crops ETc varied between $19.7 \mathrm{~mm}$ in maize to $34.8 \mathrm{~mm}$ in wheat with daily rates ranging between 1.3 to $1.9 \mathrm{~mm} \mathrm{day}^{-1}$ in different crops. During developmental stage the daily ETc was more or less same (3.0-3.2 $\left.\mathrm{mm} \mathrm{day}^{-1}\right)$ in all the crops while total ETc ranged between $92.3 \mathrm{~mm}$ in maize to $110.4 \mathrm{~mm}$ in mustard.During mid-season stage, the total ETc was maximum and ranged $183.5 \mathrm{~mm}$ in chickpea to $253.7 \mathrm{~mm}$ in wheat. The total ETc during late season stage varied between $85.9 \mathrm{~mm}$ maize to $117.2 \mathrm{~mm}$ in wheat with daily rates ranging between 3.9 to 4.7 $\mathrm{mm}$ day $^{-1}$ (Table 2). It is seen that the wheat crop has highest water requirement whereas, chickpea has lowest water requirement among winter crops. Pandey et al (2008) reported slightly less water requirement for different crops using DSSAT model while Mehta and Pandey (2015) have reported that the ETc of wheat and maize varied with the locations also. 
Table 1: Corrected and FAO Kc valuesof different crops of middle Gujarat

\begin{tabular}{|c|c|c|c|c|c|c|c|}
\hline \multirow[t]{2}{*}{ Crops } & \multirow{2}{*}{$\begin{array}{l}\mathrm{FAO} \\
\mathrm{Kc}_{\text {ini }}\end{array}$} & \multirow{2}{*}{$\begin{array}{l}\mathrm{FAO} \\
\mathrm{Kc}_{\text {mid }} \\
\end{array}$} & \multirow{2}{*}{$\begin{array}{l}\mathrm{FAO} \\
\mathrm{Kc}_{\text {end }} \\
\end{array}$} & \multirow{2}{*}{$\begin{array}{c}\text { Duration } \\
\text { (days) }\end{array}$} & \multirow{2}{*}{$\begin{array}{c}\text { Height } \\
(\mathrm{m})\end{array}$} & \multicolumn{2}{|c|}{ Corrected Kc } \\
\hline & & & & & & $\mathrm{Kc}_{\text {mid }}$ & $\mathrm{Kc}_{\text {end }}$ \\
\hline \multicolumn{8}{|c|}{ Kharif season } \\
\hline Rice & 1.05 & 1.2 & 0.9 & 120 & 0.8 & 1.20 & 0.90 \\
\hline Maize & 0.3 & 1.2 & 0.35 & 105 & 1.5 & 1.08 & 0.23 \\
\hline Pearlmillet & 0.3 & 1.0 & 0.35 & 90 & 1.5 & 0.89 & 0.19 \\
\hline Green gram & 0.4 & 1.05 & 0.6 & 90 & 0.4 & 0.96 & 0.51 \\
\hline Soybean & 0.4 & 1.15 & 0.5 & 120 & 0.6 & 1.05 & 0.40 \\
\hline Groundnut & 0.4 & 1.15 & 0.6 & 120 & 0.4 & 1.06 & 0.51 \\
\hline Cotton & 0.35 & 1.15 & 0.5 & 190 & 1.1 & 1.15 & 0.50 \\
\hline \multicolumn{8}{|c|}{ Winter season } \\
\hline Wheat & 0.4 & 1.15 & 0.41 & 120 & 0.8 & 1.15 & 0.41 \\
\hline Maize & 0.3 & 1.2 & 0.35 & 105 & 1.5 & 1.20 & 0.35 \\
\hline Chickpea & 0.4 & 1.0 & 0.35 & 120 & 0.4 & 1.00 & 0.40 \\
\hline Mustard & 0.35 & 1.15 & 0.35 & 120 & 1.3 & 1.15 & 0.35 \\
\hline \multicolumn{8}{|c|}{ Summer season } \\
\hline Pearlmillet & 0.3 & 1.0 & 0.35 & 90 & 1.5 & 1.00 & 0.30 \\
\hline Green gram & 0.4 & 1.05 & 0.6 & 90 & 0.4 & 1.05 & 0.60 \\
\hline Groundnut & 0.4 & 1.15 & 0.6 & 120 & 0.4 & 1.14 & 0.59 \\
\hline
\end{tabular}

Table 2: Stage wise total $(\mathrm{mm})$ and mean daily $\left(\mathrm{mm} \mathrm{day}^{-1}\right)$ crop water requirement (ETc) of different crops of middle Gujarat

\begin{tabular}{|c|c|c|c|c|c|c|c|c|c|}
\hline \multirow[t]{2}{*}{ Crops } & \multicolumn{2}{|c|}{ Initial stage } & \multicolumn{2}{|c|}{ Developmental stage } & \multicolumn{2}{|c|}{ Mid season stage } & \multicolumn{2}{|c|}{ Late season stage } & \multirow{2}{*}{$\begin{array}{c}\text { Seasonal } \\
\text { total }\end{array}$} \\
\hline & Total & Daily & Total & Daily & Total & Daily & Total & Daily & \\
\hline \multicolumn{10}{|c|}{ Kharif season } \\
\hline Rice & 83.8 & 5.6 & 171.1 & 5.7 & 312.0 & 6.9 & 162.4 & 5.4 & 729.3 \\
\hline Maize & 34.5 & 2.3 & 114.1 & 3.8 & 222.8 & 5.6 & 74.0 & 3.7 & 445.4 \\
\hline Pearlmillet & 24.0 & 1.6 & 76.0 & 3.1 & 176.8 & 5.1 & 46.8 & 3.1 & 323.6 \\
\hline Green gram & 32.0 & 2.1 & 66.5 & 3.3 & 161.9 & 5.4 & 64.2 & 4.3 & 324.6 \\
\hline Soybean & 59.0 & 3.0 & 115.6 & 3.6 & 253.2 & 5.6 & 105.5 & 4.2 & 533.3 \\
\hline Groundnut & 59.0 & 3.0 & 132.6 & 3.8 & 230.5 & 5.8 & 114.4 & 4.6 & 536.5 \\
\hline Cotton & 71.5 & 2.4 & 173.9 & 3.9 & 422.1 & 6.5 & 180.5 & 3.6 & 848.0 \\
\hline \multicolumn{10}{|c|}{ Winter season } \\
\hline Wheat & 34.8 & 1.8 & 95.5 & 3.2 & 253.7 & 5.6 & 117.2 & 4.7 & 501.2 \\
\hline Maize & 19.7 & 1.3 & 92.3 & 3.1 & 222.4 & 5.6 & 85.9 & 4.3 & 420.3 \\
\hline Chickpea & 28.1 & 1.9 & 103.3 & 3.0 & 183.5 & 4.1 & 96.8 & 3.9 & 411.7 \\
\hline Mustard & 24.7 & 1.6 & 110.4 & 3.2 & 231.0 & 5.1 & 103.0 & 4.1 & 469.1 \\
\hline \multicolumn{10}{|c|}{ Summer season } \\
\hline Pearlmillet & 26.6 & 1.8 & 110.8 & 4.4 & 278.0 & 7.9 & 83.8 & 5.6 & 499.2 \\
\hline Green gram & 35.5 & 2.4 & 95.8 & 4.8 & 241.7 & 8.0 & 103.5 & 6.9 & 476.5 \\
\hline Groundnut & 48.1 & 2.4 & 196.2 & 5.6 & 398.0 & 9.9 & 206.7 & 8.3 & 849.0 \\
\hline
\end{tabular}


ETc of summer crops: During summer season the crop water requirement for all the crops (pearlmillet, green gram and groundnut) were higher than those during kharif season. The highest ETc $(849.0 \mathrm{~mm})$ was in groundnut followed by pearl millet $(499.2 \mathrm{~mm})$ and green gram $(476.5$ $\mathrm{mm})$. The stage wise water requirement varied between 26.6 to $48.1 \mathrm{~mm}, 95.8$ to $196.2 \mathrm{~mm}, 241.7$ to $398.0 \mathrm{~mm}$ and 83.8 to $206.7 \mathrm{~mm}$ during its initial, developmental, mid season and late season stages respectively. The daily rates of ETc of different crops were lowest ( 1.8 to $2.4 \mathrm{~mm} \mathrm{day}^{-1}$ ) during initial stage and maximum ( 7.9 to $9.9 \mathrm{~mm} \mathrm{day}^{-1}$ ) during midseason stage. Green gram has the lowest ETc whereas, groundnut has highest crop water requirement among summer crops.

\section{CONCLUSION}

The crop water requirement (ETc) was found to vary not only with the crops its stage and duration, but also with the season as well. The crops differed in water demand as the growing season changed. During initial stage of the crops, the ETc was less and increased during development stage, reached to its maximum values during mid season and reduced during crop maturation stages. ETc was maximum for summer season crops followed by kharif season and lowest in winter season. The information generated can be used in scheduling irrigation for different crops of middle Gujarat.

\section{ACKNOWLEDGEMENT}

The authors gratefully acknowledge the cooperation extended by Dr Anil Kumar and Dr Manoj Lunagaria of the department in analysis work.

\section{REFERENCES}

Allen, R. G., Pereira, L. S., Raes, D. and Smith, M. (1998). Crop Evapotranspiration: Guidelines for computing crop water requirements. Irrigation and Drainage Paper 56, FAO of the United Nations, Rome. 300 pp.

Blaney, H. F, and Criddle, W. D. (1950). Determining water requirements in irrigated areas from climatological and irrigation data. Technical Paper No. 96, United States Department of Agriculture, Soil Conservation Service, Washington. 44pp.

Christiansen, J. E. (1968). Pan evaporation and evapotranspiration from climatic data. J. Irrig.Drain.
Divis., ASCE 94: 243-265.

Doorenbos, J.and Pruitt, W. O. (1975). Guidelines for predicting crop water requirements, Irrigation and Drainage Paper 24, FAO of the United Nations, Rome. 179 pp.

Hargreaves, G. H. and Samani, Z. A. (1985). Reference evapotranspiration from temperature. American Soc.Agril. Engg., 1(2):96-99.

Irmak, S., Allen, R. G. and Whitty, E. B. (2003).Dailygrass and alfalfa-referenceevapotranspiration estimates and alfalfa to grass evapotranspiration ratios in Florida. J. Irrig. Drain. Engg.129(5):360-370.

Jensen, M. E., Burman, R. D. and Allen, R. G. (1990). Evapotranspiration and irrigation water requirements,ASCE manuals and reports on engineering practice, No. 70, ASCE, New York.

Kashyap, P. S. and Panda, R. K. (2001).Evaluation of evapotranspiration estimationmethods and development of crop-coefficientsfor potato crop in subhumid region. Agril. Water Manag., 50:9-25.

Kumar, J. and Singh,A. K. P. (2006). Crop coefficient models of wheat and maize for irrigation planning in Gandak command. J. Indian Water Res. Soci.,26(2):14-15.

Mehta, R. and Pandey, V.(2015).Reference evapotranspiration (ETo) and crop water requirement (ETc) of wheat and maize in Gujarat. J. Agrometeorol.,17(1):107-113.

Pandey, V. Patel, V.J. Vadodaria, R.P. Patel, H.R. and Shekh,A.M. (2008). Irrigation water requirement and production potentials of major crops over Narmada canal command area in Gujarat, J. Agrometeorol., 10(Special issue-2): $341-320$.

Priestley, C. H. B. and Taylor, R. J. (1972). On the assessment of surface heat flux and evaporation using large scale parameters. Monthly Weather Review, 100:81-92.

Shankar, V., Ojha, C. S. P. and Prasad, H. K. S. (2012). Irrigation scheduling for maize and Indian-mustard based on daily crop water requirement in a semiarid region. World Acad. Sci.Engg. Tech.,6:476-485.

Turc, L. (1961). Estimation of irrigation water requirements, potential evapotranspiration: A simple climatic formula evolved up to date. Ann. Agron., 12:13-49. 